ISSN: 2302-8556

E-Jurnal Akuntansi Universitas Udayana

Vol.26.2.Februari (2019): 1570-1600

DOI: https://doi.org/10.24843/EJA.2019.v26.i02.p27

\title{
Efektivitas Komite Audit dan Audit Internal terhadap Kasus Kecurangan dengan Whistleblowing System sebagai Variabel Pemoderasi
}

\author{
Luh Utami ${ }^{1}$ \\ Lilik Handajani \\ Hermanto ${ }^{3}$ \\ 1,2,3 Fakultas Ekonomi dan Bisnis Universitas Mataram (Unram), NTB, Indonesia \\ e-mail: dindaparameswari12@gmail.com
}

\begin{abstract}
ABSTRAK
Penelitian bertujuan menguji pengaruh efektivitas komite audit dan audit internal terhadap pengungkapan kasus kecurangan dengan whistleblowing system sebagai pemoderasi. Populasi penelitian adalah perusahaan terdaftar di BEI tahun 2016-2017 dan mengungkapkan whistleblowing system. Sampel ditentukan dengan purposive sampling diperoleh 102 sampel. Alat analisis data menggunakan Moderated Regression Analysis (MRA). Temuan penelitian menunjukkan whistleblowing system memperkuat pengaruh komite audit dan audit internal untuk mengungkap kasus kecurangan. Implikasi penelitian ini dapat berguna sebagai pertimbangan bagi perusahaan dalam membuat kebijakan terkait pengungkapan whistleblowing system.
\end{abstract}

Kata Kunci : Komite Audit, Audit Internal, Whistleblowing System, Kasus Kecurangan

\begin{abstract}
The study aims to examine the effect of the effectiveness of the audit committee and internal audit on disclosure of fraud cases with a whistleblowing system as moderating. The research population of the company is listed on the Indonesia Stock Exchange in 2016-2017 and discloses whistleblowing system reporting. The sample was determined by purposive sampling obtained 102 samples. The data analysis tool is used Moderated Regression Analysis (MRA). The research findings indicate a whistleblowing system strengthens the influence of audit and internal audit committees to uncover fraud cases. The implications of this research can be useful as a consideration for companies in making policies related to disclosure of whistleblowing systems. Keywords: Audit Committee, Internal Audit, Whistleblowing System, Fraud Cases
\end{abstract}

\section{PENDAHULUAN}

Kasus Kecurangan (fraud) merupakan topik hangat yang sering menjadi bahan utama berita baik di media masa maupun media elektronik. Kecurangan dapat terjadi terjadi dimana saja seperti organisasi non profit, perusahaan maupun lembaga pemerintahan. Hasil penelitian Association of Certified Fraud Examiners Global (ACFE, 2016) menunjukkan bahwa fraud merupakan bahaya laten yang mengancam dunia karena bukan hanya terjadi di negara berkembang seperti 
Indonesia tetapi juga negara-negara maju. Setiap tahun rata-rata 5\% dari pendapatan organisasi menjadi korban kecurangan (fraud) (ACFE Indonesia, 2016). Kecurangan dapat dibuktikan dengan adanya penyalahgunan asset, manipulasi pajak, laporan keuangan, dan penyuapan individu ke lembaga pemerintahan.

Menurut Association of Certified Fraud Examiners (ACFE,2016), fraud (kecurangan) dikelompokkan menjadi 3 (tiga) jenis, yaitu: fraud aset (Asset Misappropriation), fraud laporan keuangan (Fraudulent Statements), dan korupsi (Corruption). Di Indonesia korupsi merupakan jenis fraud yang paling banyak merugikan. Berdasarkan hasil survei ACFE Indonesia, besarnya kerugian yang disebabkan fraud dapat dilihat Tabel 1:

\section{Tabel 1.}

Kerugian Fraud Berdasarkan Jenis Fraud

\begin{tabular}{llccc}
\hline No & Jumlah Kerugian & $\begin{array}{l}\text { Korupsi } \\
\text { (Corruption). }\end{array}$ & $\begin{array}{l}\text { Aset (Asset } \\
\text { Misappropriation }\end{array}$ & $\begin{array}{c}\text { Fraudulent } \\
\text { Statements }\end{array}$ \\
\hline 1. & < Rp. 10 Juta & 5 & 2 & 0 \\
& & 11 & 6 & 0 \\
2. & $\begin{array}{l}\text { Rp. 10 Juta sampai dengan } \\
\text { <Rp.50 Juta }\end{array}$ & 36 & 11 & 0 \\
3. & $\begin{array}{l}\text { Rp.100 Juta s/d < Rp.500 Juta } \\
\text { R. }\end{array}$ & 32 & 7 & 2 \\
5.500 Juta s/d 1 Milyar & Rp. 1 Milyar s/d 5 Milyar & 29 & 4 & 1 \\
6. & Rp.5 Milyar s/d 10 Milyar & 16 & 2 & 0 \\
7. & Diatas Rp.10 Milyar & 23 & 9 & 4 \\
& Jumlah & 170 & 48 & 7 \\
\hline
\end{tabular}

Sumber: Survei Fraud Indonesia, 2016

BerdasarkanTabel 1, korupsi merupakan jenis fraud dengan jumlah kasus yang paling tinggi yakni sebanyak 170 kasus dengan modus kerugian Rp.100 juta sampai dengan Rp.500 Juta sehingga menjadi kasus fraud yang paling merugikan 
di Indonesia. Penyalahgunaan asset menempati posisi ke dua sebanyak 48 kasus dan modus kerugian yang sama besar dengan korupsi. Kasus fraud laporan keuangan memang paling sedikit yakni hanya 7 kasus tetapi modus kerugian yang diakibatkan fraud ini sangat besar yakni mulai dari Rp.500 Juta hingga diatas Rp.10 Milyar. Dapat disimpulkan bahwa fraud yang terjadi menyebabkan kerugian yang sangat material sehingga diperlukan kerjasama semua pihak dalam memerangi fraud yang mungkin terjadi baik dari pihak intern maupun ekstern organisasi.

Menurut Fraud Tiangle Theory yang dikemukakan oleh Crassey (1953) fraud terjadi karena adanya tekanan, kesempatan dan rasionalisasi. Secara simultan ketiga hal tersebut akan mendorong suatu pihak untuk berada pada suatu kondisi moral yang menjustifikasi tindak kecurangan yang di dalammya terdapat karyawan dan pihak pihak yang berkepentingan. Teory of Planned Behaviour (TPB) yang dikemukakan oleh Ajzen (1991) menyebutkan bahwa ada 3 faktor yang mempengaruhi prilaku seseorang yaitu attitude (sikap), subjective norm (norma subyektif) dan perceived behaviour control (kontrol prilaku) . Ketiga faktor tersebut akan bersama-sama mempengaruhi seluruh elemen perusahaan terhadap tindak kecurangan.

Struktur tata kelola yang memiliki tugas dan tanggung jawab terkait kecurangan adalah komite audit dan audit internal. Berdasarkan Peraturan Otoritas Jasa Keuangan (OJK) No.55/PJOK.04/2015, anggota komite audit diisyaratkan independen dan sekurang- kurangnya ada satu orang memiliki kemampuan dibidang akuntansi atau keuangan. Independensi yang dimaksudkan 
bahwa anggota dan ketua komite audit bersifat independen serta tidak memiliki koneksi keuangan dan tidak memiliki hubungan keluarga ataupun bisnis dengan anggota dewan Komisaris atau Direksi atau pemegang saham mayoritas lain. Kartika dan Sudarno (2014) menyatakan bahwa Komite audit independen berpengaruh signifikan terhadap kecurangan. Sedangkan dalam penelitian yang dilakukan oleh Prasetyo ( 2014) dan Dwiputri (2013) menyatakan bahwa Independensi komite audit berpengaruh tidak signifikan terhadap kecurangan.

Audit internal juga melakukan pemeriksaan untuk menjamin apakah proses pengendalian perusahaan sudah dilakukan dengan baik. Hasil dari survai fraud Indonesia pada tahun 2016 menunjukkan bahwa audit internal efektif mengungkap fraud berdasarkan besarnya nilai kerugian yang ditimbulkan oleh kasus fraud tersebut. Beberapa penelitian tentang pengaruh audit internal terhadap fraud dilakukan oleh Festi, Andreas \& Natariasari (2014), Noviani dan Shambarakresna (2014), Widaningsih \& Hakim (2015) dan hasilnya menunjukkan bahwa audit internal berpengaruh signifikan terhadap kecurangan. Semakin baik audit internal maka pencegahan kecurangan akan semakin tinggi sehingga mengurangi kasus kecurangan yang terjadi pada perusahaan. Penelitian yang dilakukan oleh Zelmiyati \& Anita (2015) menunjukkan hasil yang berbeda, dimana audit internal berpengaruh tidak signifikan terhadap kecurangan.

Pada tahun 2008 Komite Nasional Kebijakan Governance merilis sistem pelaporan pelanggaran. Sistem ini berada dibawah komite audit dan hasil dari pelaporan yang masuk akan ditindaklanjuti oleh audit internal. Laporan yang dimaksud disini adalah laporan dari pihak intern atau manajemen perusahaan 
melalui whistleblowing system (KNKG,2008). Efektivitas sistem tersebut terlihat dari jumlah kecurangan yang berhasil dideteksi dan juga waktu penindakannya yang relatif lebih singkat dibandingkan dengan cara lainnya. Selain itu, pimpinan perusahaan memiliki kesempatan untuk mengatasi permasalahan secara internal dulu, sebelum permasalahan tersebut merebak ke ruang publik yang dapat mempengaruhi reputasi perusahaan.

Beberapa penelitian sebelumnya tentang whistleblowing system sudah banyak dilakukan diantarannya Nurcahyo \& Sulhani (2017) dan Mustika (2016) yang menguji pengaruh whistleblowing system terhadap fraud. Hasil penelitian tersebut menunjukkan bahwa whistleblowing system tidak berpengaruh terhadap fraud. Penelitian ini dilakukan untuk menguji pengaruh efektivitas komite audit dan audit internal dalam pengungkapan kasus kecurangan dengan whistleblowing system sebagai variabel pemoderasi pada perusahaan yang terdaftar di BEI tahun $2016-2017$

Berdasarkan latar belakang masalah diatas maka dapat dirumuskan masalah sebagai berikut: 1. Apakah independensi komite audit berpengaruh negatif terhadap pengungkapan kasus kecurangan? 2. Apakah keahlian keuangan komite audit berpengaruh negatif terhadap pengungkapan kasus kecurangan? 3. Apakah keahlian keuangan Audit Internal berpengaruh negatif terhadap pengungkapan kasus kecurangan? 4. Apakah Independensi Audit Internal berpengaruh negatif terhadap pengungkapan kasus kecurangan? 5. Apakah whistleblowing system memperkuat pengaruh independensi komite audit terhadap pengungkapan kasus kecurangan? 6. Apakah whistleblowing system memperkuat pengaruh keahlian 
keuangan komite audit terhadap pengungkapan kasus kecurangan? 7. Apakah whistleblowing system memperkuat pengaruh keahlian keuangan audit internal terhadap pengungkapan kasus kecurangan? 8. Apakah whistleblowing system memperkuat pengaruh jumlah audit yang dilakukan oleh audit internal terhadap pengungkapan kasus kecurangan?

Berdasarkan latar belakang dan rumusan masalah diatas maka tujuan penelitian ini adalah 1. Menguji pengaruh independensi komite audit terhadap pengungkapan kasus kecurangan. 2. Menguji pengaruh keahlian keuangan komite audit terhadap pengungkapan kasus kecurangan. 3. Menguji pengaruh keahlian keuangan audit internal terhadap pengungkapan kasus kecurangan. 4. Menguji pengaruh jumlah audit yang dilakukan audit internal terhadap pengungkapan kasus kecurangan 5. Menguji pengaruh independensi komite audit terhadap pengungkapan kasus kecurangan dengan whistleblowing system sebagai pemoderasi. 6. Menguji pengaruh keahlian keuangan komite audit terhadap pengungkapan kasus kecurangan dengan whistleblowing system sebagai pemoderasi. 7. Menguji pengaruh keahlian keuangan audit internal terhadap pengungkapan kasus kecurangan dengan whistleblowing system sebagai pemoderasi 8. Menguji pengaruh jumlah audit yang dilakukan audit internal terhadap pengungkapan kasus kecurangan dengan whistleblowing system sebagai pemoderasi.

Adapun Grand Theory yang mendasari penelitian ini adalah Fraud Triangle Theory dan Theory of Planned Behaviour (TPB). Theory of planned behaviour merupakan bentuk penyempurnaan dari teori sebelumnya yaitu theory of reasoned 
action oleh Ajzen (1991). Theory of planned behaviour menjelaskan mengenai perilaku yang dilakukan individu timbul karena adanya niat dari individu tersebut untuk berperilaku dan niat individu disebabkan oleh beberapa faktor internal dan eksternal dari individu tersebut. Perilaku yang dipengaruhi secara internal adalah perilaku yang diyakini berada di bawah kendali pribadi individu itu sendiri dalam keadaan sadar, sedangkan perilaku yang disebabkan secara eksternal adalah perilaku yang dipengaruhi dari luar atau dipengaruhi oleh individu lain. Theory of planned behaviour ini didasarkan pada asumsi bahwa manusia adalah makhluk yang rasional yang akan memperhitungkan implikasi dari tindakan mereka sebelum memutuskan untuk melakukan suatu perilaku yang akan mereka lakukan. Menurut Theory of Planned Behaviour munculnya niat berprilaku ditentukan oleh tiga faktor yaitu: behavior beliefts, normative beliefs, dan control beliefs. Tiga faktor tersebut bersama-sama mempengaruhi motivasi individu terpelajar tersebut untuk melakukan Whistleblowing dalam upaya untuk mengindari kecurangan dan ditularkan kepada keluarga serta rekan kerjanya. Niat individu tersebut untuk menghindari kecurangan cukup kuat, sehingga pada akhirnya memutuskan untuk terus tidak melakukan kecurangan. Theory Planned Behaviour diprediksi dapat mempengaruhi minat seseorang dalam melakukan whistleblowing untuk mengungkap kecurangan baik yang berpotensi terjadi maupun yang sudah terjadi pada perusahaan.

Kassem dan Higson (2012) menjelaskan bahwa penelitian tentang fraud pertama kali dilakukan oleh seorang kriminolog bernama Donald Cressey pada 1950, yang meneliti tentang motivasi yang mendorong orang melanggar 
Luh Utami, Lilik Handajani dan Hermanto. Evektifitas ...

kepercayaan yang diberikan kepadanya. Selama 5 bulan mewawancarai 250 penjahat yang perilakunya memenuhi dua kriteria, a) orang tersebut harus telah menerima posisi kepercayaan dengan itikad yang baik, dan b) ia harus telah melanggar kepercayaan. Berdasarkan penelitian tersebut, akhirnya Cressey pada 1953 melahirkan Fraud Triangle Theory dalam bukunya "Other People's Money", yakni tiga faktor yang menyebabkan seseorang melanggar kepercayaan dan melakukan tindak kecurangan yakni pressure (tekanan), opportunity (kesempatan) serta rationalization (rasionalisasi).

Secara sistematis rerangka konseptual penelitian ini dapat dilihat pada gambar 1 sebagai berikut:

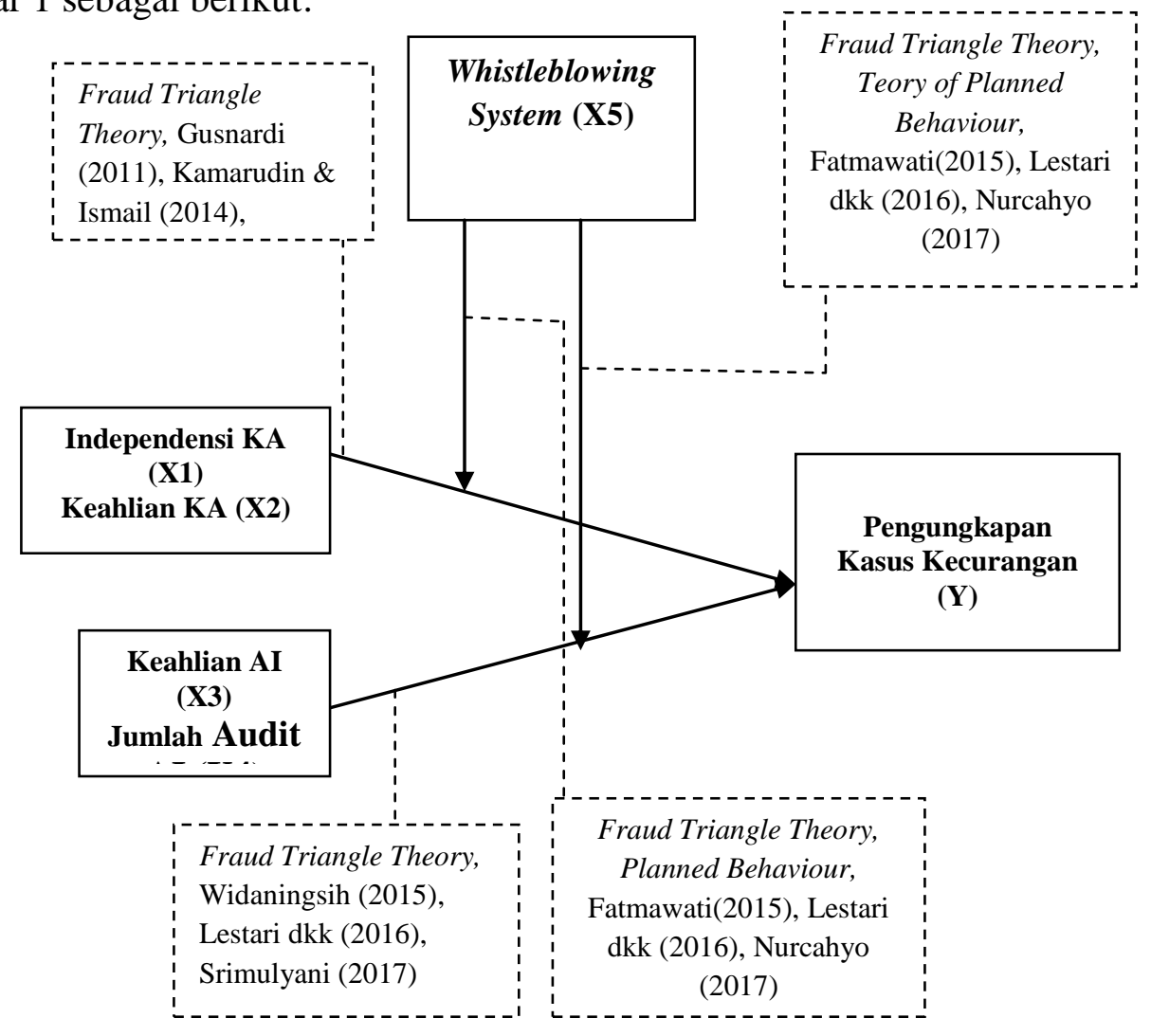

Gambar 1. Kerangka Konseptual Penelitian

Sumber : Data diolah, 2019 
Penelitian yang sebelumnya dilakukan oleh Raghundan et al. (2001) dalam Huang dan Thiruvandi (2010) menemukan bahwa komite audit yang terdiri setidaknya satu anggota memiliki latar belakang keuangan atau akuntansi akan memperkecil kemungkinan kecurangan. Semakin banyak komite audit yang memiliki keahlian keuangan maka efektivitas komite audit akan semakin meningkat. Hal ini terkait dengan peran dan tanggung jawab komite audit tentang pelaporan keuangan dan manajemen. Keahlian keuangan yang dimiliki oleh komite audit akan membantu mendeteksi potensi kecurangan yang mungkin atau sudah terjadi melalui pemeriksaan laporan keuangan.

$\mathrm{H}_{1}$ : Independensi komite audit berpengaruh negatif terhadap pengungkapan kasus kecurangan

$\mathrm{H}_{2}$ : Keahlian keuangan komite audit berpengaruh terhadap pengungkapan kasus kecurangan

Menurut Peraturan Otoritas Jasa Keuangan NO.56/PJOK.04/2015 tentang pembentukan dan penyusunan piagam unit audit internal menyatakan bahwa audit internal harus memiliki keahlian keuangan, akuntansi dan keahlian. Keahlian tersebut terkait dengan tugas dan wewenang komite audit dalam melakukan pemeriksaan dan penilaian atas efisiensi dan efektivitas dibidang keuangan, akuntansi dan bidang lainnya. Penelitian tentang pengaruh audit internal terhadap fraud dilakukan oleh Festi, Andreas \& Natariasari (2014), Noviani dan Shambarakresna (2014), Widaningsih \& Hakim ( 2015), Lestari dkk ( 2016 ) dan hasil dari penelitian - penelitian tersebut menunjukkan bahwa audit internal berpengaruh terhadap fraud.

$\mathrm{H}_{3}$ : Keahlian keuangan audit internal berpengaruh negatif terhadap pengungkapan kasus kecurangan. 
$\mathrm{H}_{4}$ : Jumlah audit oleh audit internal berpengaruh negatif terhadap pengungkapan kasus kecurangan.

Dalam pedomaan komite audit yang efektif disebutkan bahwa disyaratkan bahwa anggota komite audit berasal dari pihak independen dan paling sedikit 1 orang anggota komite audit memiliki pengertian yang baik tentang pelaporan keuangan. Hal ini terkait dengan tugas utama komite audit termasuk pemeriksaan dan penawasan proses pelaporan keuangan dan kontrol internal. Kontrol internal disini erat kaitannya dengan kebijakan anti fraud perusahaan. Dalam penelitian yang dilakukan oleh Prasetyo ( 2017) menyebutkan bahwa komite audit berpengaruh terhadap fraud, hasil penelitian tersebut juga didukung oleh penelitian yang dilakukan Handoko \& Ramdhani (2017).

Keberhasilan dari pelaksanaan Whistleblowing System sangat bergantung pada efektivitas dari komite audit. Hal ini disebabkan karena system tersebut berada dibawah tanggung jawab komite audit ( KNKG,2008). Whistleblowing system yang berada dibawah kepengurusan komite audit diharapkan dapat membantu tugas komite audit. Dalam penelitian yang diakukan oleh Cahyo \& Sulhani (2017) yang meneliti pengaruh langsung Whistleblowing System terhadap kecurangan menyebutkan bahwa whistleblowing system tidak berpengaruh terhadap kecurangan.

$\mathrm{H}_{5}$ : Whistleblowing system memperkuat pengaruh independensi komite audit terhadap pengungkapan kasus kecurangan.

$\mathrm{H}_{6}$ : Whistleblowing system memperkuat pengaruh keahlian keuangan komite audit terhadap pengungkapan kasus kecurangan.

Dalam penelitian yang dilakukan oleh Kusumawardhani (2014) menyebutkan bahwa ineffektive Monitoring berpengaruh terhadap fraud. Audit 
Internal sebagai bagian pengendalian dalam perusahaan diharapkan dapat melakukan pendeteksian terhadap terjadinya kecurangan. Salah satu tingkat efektivitas dari audit internal dapat dilihat dari keahlian keuangan kepala unit audit internal dan jumlah audit yang dilakukan dalam setahun . Audit internal juga melakukan tugasnya audit internal juga berpedoman kepada laporan laporan yang masuk melalui whistleblowing system. Audit internal akan melakukan audit investigatif atas laporan - laporan yang terindikasi adanya praktik kecurangan (fraud) Chartered Institute of Internal Auditors, 2014; National Audit Office (2014). Whistleblowing system yang merupakan bagian dari pengendalian internal. Pelaksanaan pengendalian internal yang optimal mampu mendeteksi indikasi praktik kecurangan secara dini (Coram et al. 2008; Protiviti, 2009). Hal ini didukung hasil survey yang dilakukan oleh Waldron pada tahun 2012 menunjukkan bahwa mayoritas laporan yang diterima melalui whistleblowing system. Hasil survei tersebut juga menunjukkan bahwa sebagian besar laporan dalam whistleblowing system ditangani oleh bagian audit internal perusahaan.

Penelitian yang dilakukan oleh Read \& Rama (2003) menyimpulkan bahwa audit internal merupakan pihak yang berperan penting dalam pelaksanaan whistleblowing system. Audit internal akan melakukan audit investigatif atas laporan-laporan yang terindikasi adanya praktik kecurangan (fraud) dan kemudian melaporkan hasilnya kepada Komite Audit (Komite Nasional Kebijakan Governance, 2008). 
Pelaksanaan audit investigatif oleh audit internal memerlukan keahlian dalam bidang audit baik secara keuangan maupun non-keuangan agar memperoleh hasil audit yang optimal (Davies 2009). Keahlian dalam bidang audit dapat diberikan kepada auditor internal melalui pelatihan-pelatihan yang berkaitan dengan penilaian risiko fraud (Sanusi 2015). Penelitian ini menambahkan interaksi whistleblowing system dalam mempengaruhi audit internal dalam upaya pengungkapan kasus kecurangan. Penerapan whistleblowing system akan membantu seorang auditor dalam mengidentifikasi resiko fraud secara lebih cepat dan tepat melalui laporan yang masuk melalui whistleblowing system.

$\mathrm{H}_{7}$ : Whistleblowing system memperkuat pengaruh keahlian keuangan audit internal terhadap pengungkapan kasus kecurangan.

$\mathrm{H}_{8}$ : Whistleblowing system memperkuat pengaruh jumlah audit oleh audit internal terhadap pengungkapan kasus kecurangan.

\section{METODE PENELITIAN}

Penelitian ini menggunakan pendekatan kuantitatif. Penelitian kuantitatif dilakukan dengan mengumpulkan data berupa angka yang kemudian diolah dan dianalisis untuk mendapatkan suatu informasi ilmiah yang hasilnya dapat digeneralisasi (Martono,2012:23). Berdasarkan jenisnya penelitian ini adalah penelitian eksplanatori. Penelitian eksplanatori merupakan penelitian penjelasan yang menyoroti hubungan kausal antara variabel-variabel penelitian dan menguji hipotesis yang telah dirumuskan sebelumnya ( Zulganef, 2008:11). Penelitian ini dilakukan pada perusahaan terdaftar di Bursa Efek Indonesia ( BEI) yang melaporkan whistleblowing system pada tahun 2016 sampai tahun 2017. 
Populasi adalah wilayah generalisasi yang terdiri atas obyek / subyek yang mempunyai kualitas dan karakteristik tertentu yang ditetapkan oleh peneliti untuk dipelajari dan kemudian ditarik kesimpulannya (Sugiyono, 2014:115). Obyek penelitian adalah variabel atau apa yang menjadi titik perhatian suatu penelitian, sedangkan subyek penelitian adalah tempat dimana obyek melekat (Arikunto,2002:15). Sedangkan sampel adalah bagian dari jumlah dan karakteristik yang dimiliki oleh populasi tersebut. Teknik pengambilan sampel penelitian ini dengan pendekatan purposive sampling yaitu teknik pengambilan sampel dengan pertimbangan tertentu (Sugiyono, 2014:122). Purposive Sampling digunakan karena data yang akan diambil berasal dari sumber yang sengaja dipilih berdasarkan kriteria yang telah ditetapkan peneliti antara lain:

\section{Tabel 2.}

\section{Perhitungan Sampel}

\begin{tabular}{llc}
\hline No & \multicolumn{1}{c}{ Kriteria Pemilihan Sampel } & Jumlah \\
\hline 1 & $\begin{array}{l}\text { Perusahaan yang melaporkan whistleblowing system } \\
\text { selama tahun 2016 sampai dengan 2017 } \\
4\end{array}$ & $\begin{array}{l}\text { Perusahaan yang tidak melaporkan pengungkapan kasus } \\
\text { kecurangan }\end{array}$ \\
5 & $\begin{array}{l}\text { Perusahaan yang tidak menyajikan informasi mengenai } \\
\text { komite audit secara lengkap } \\
\text { Perusahaan yang tidak melaporkan mengenai audit } \\
\text { internal secara lengkap } \\
\text { Perusahaan yang memenuhi kreteria sampel } \\
\text { Jumlah Sampel (51x 2 tahun ) }\end{array}$
\end{tabular}

Sumber: Data diolah, 2017

Variabel independen ( terikat) dalam penelitian ini adalah komite audit dan audit internal. Komite audit diukur dengan dua proksi yaitu rasio anggota komite independen $\left(\mathrm{X}_{1}\right)$ ( Handoko \& Ramdhani, 2017) dan rasio anggota komite audit yang memiliki keahlian keuangan dan akuntansi $\left(\mathrm{X}_{2}\right)$ (Handoko \& Ramdhani, 2017). Audit internal diukur dengan keahlian keuangan kepala unit audit internal $\left(\mathrm{X}_{3}\right)$ (Nurcahyo \& Sulhani, 2017) dan jumlah audit yang dilakukan audit internal 
dalam setahun $\left(\mathrm{X}_{4}\right)$ (Nurcahyo \& Sulhani, 2017). Sedangkan variabel moderasi atau interaksi dalam penelitian ini adalah whistleblowing system (X3). Whistleblowing system diukur dengan rasio laporan whistleblowing system yang dilaksanakan perusahaan berdasarkan pada pedoman sistem pelaporan pelanggaran (KNKG,2008). Variabel dependen (bebas) dalam penelitian ini adalah pengungkapan kasus kecurangan. Pengungkapan kasus kecurangan diukur dengan jumlah kasus kecurangan yang dilaporkan perusahaan pada laporan tahunan ( Nurcahyo \& Sulhani,2017).

Alat analisis yang digunakan dalam penelitian ini adalah regresi linier berganda dengan SPSS 23, Sebelum pengolahan data dengan regresi linier berganda terlebih dahulu dilakukan uji asumsi klasik untuk memastikan tidak terjadi normalitas, multikolinearitas, heteroskedastisitas, dan autokorelasi. Apabila uji asumsi klasik sudah terpenuhi, pengujian hipotesis penelitian ini dilakukan dengan menggunakan model Moderated Regression Analysis (MRA). Uji interaksi ini merupakan aplikasi khusus regresi linier berganda dimana dalam persamaan regresinya mengandung unsur interaksi ( perkalian dua atau lebih variabel independen (Ghozali,2013). Model persamaan yang digunakan adalah sebagai berikut:

$$
\begin{array}{r}
\mathrm{Y}=\alpha+\beta_{1} \mathrm{X}_{1}+\beta_{2} \mathrm{X}_{2}+\beta_{3} \mathrm{X}_{3}+\beta_{4} \mathrm{X}_{4}+\beta_{5} \mathrm{X}_{5}+\beta_{6} \mathrm{X}_{1} * \mathrm{X}_{5}+\beta_{7} \mathrm{X}_{2} * \mathrm{X}_{5}+\beta_{8} \mathrm{X}_{3} * \mathrm{X}_{5+} \\
\mathrm{e} \beta_{9} \mathrm{X}_{4} * \mathrm{X}_{5}+\mathrm{e} \ldots \ldots \ldots \ldots \ldots \ldots \ldots \ldots \ldots \ldots \ldots \ldots \ldots \ldots \ldots \ldots \ldots \ldots \ldots \ldots \ldots \ldots \ldots \ldots \ldots \ldots \ldots \ldots \ldots \ldots \ldots \ldots \ldots \ldots \ldots \ldots \ldots \ldots \ldots \ldots \ldots \ldots \ldots \ldots \ldots \ldots \ldots
\end{array}
$$

Keterangan:

$\mathrm{Y} \quad$ : Pengungkapan kasus kecurangan

$\mathrm{X}_{1} \quad$ : Independensi Komite audit

$\mathrm{X}_{2}$ : Keahlian Keuangan komite audit

$\mathrm{X}_{3}$ : Keahlian keuangan audit internal

$\mathrm{X}_{4} \quad$ :Jumlah audit oleh audit internal 


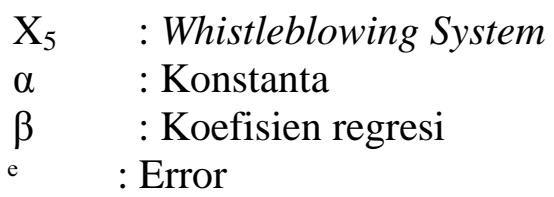

\section{HASIL DAN PEMBAHASAN}

Uji asumsi klasik dalam penelitian ini meliputi uji normalitas, uji autokorelasi, uji mutikolinearitas dan uji heteroskedastisitas. Uji normalitas menggunakan uji nonparametrik satu sampel kolmogorov-smirnov yang bertujuan untuk menguji apakah dalam model regresi, variabel pengganggu atau resedual memiliki distribusi normal. Dalam penelitian ini normalitas diuji dengan uji KolmogorovSmirnov (K-S). Data dikatakan berdistribusi normal jika Asymp. Sig ( 2-tiled) lebih besar dari $\alpha=0,05$. Berikut adalah tabel uji kolmogorov-smirnov:

Tabel 3.

Hasil uji Normalitas

\begin{tabular}{ccc}
\hline & & Unstandardized Residual \\
\hline $\mathrm{N}$ & Mean & 102 \\
Normal Parameters $^{\mathrm{a}, \mathrm{b}}$ & Std. Deviation &, 0000000 \\
& Absolute &, 93691773 \\
Most Extreme Differences & Positive &, 067 \\
& Negative &, 045 \\
Test Statistic & &,- 067 \\
Asymp. Sig. (2-tailed) & &, 067 \\
\hline Sumber: & &, 200 \\
\hline
\end{tabular}
Sumber : Data diolah, 2019

Berdasarkan tabel diatas, nilai Asymp. Sig (2-tiled) sebesar 2,00>0,05, maka dapat disimpulkan bahwa data residual berdistribusi normal. Model regresi yang baik adalah model regresi yang tidak mengalami multikolinealitas. Multikolonialitas dapat dilihat dari tolerance atau variance inflation factor (VIF). Jika ada nilai tolerance lebih dari 10 persen dan nilai VIF kurang dari 10 persen maka dapat diartikan bahwa tidak ada gejala multikolonialitas. Berikut hasil pengujian multikolonialitas. 
Tabel 4.

Hasil Uji Multikolonialitas

\begin{tabular}{cccc}
\hline & & \multicolumn{2}{c}{ Collinearity Statistics } \\
\cline { 3 - 4 } Model & & Tolerance & VIF \\
\hline 1 & (Constant) & & \\
X1 &, 510 & 1,959 \\
X2 &, 503 & 1,987 \\
X3 &, 961 & 1,041 \\
X4 &, 981 & 1,019 \\
& X5 &, 828 & 1,208 \\
\hline
\end{tabular}

Sumber : Data diolah, 2019

Berdasarkan tabel diatas hasil pengujian menunjukkan bahwa variable varisabel dalam penelitian ini memiliki tolerance lebih dari 10 persen atau nilai VIF kurang dari 10 persen yang mengindikasikan bahwa tidak ada multikolonialitas antar variable independen.

Uji heteroskedastisitas bertujian menguji apakah dalam model regresi terjadi ketidaksamaan variance dari residual atau pengamatan ke pengamatan yang lain. Jika variance dari residual satu pengamatan ke pengamatan lain tetap, maka disebut homoskedastisitas atau tidak terjadi homoskedastisitas. Dalam penelitian ini, untuk mendeteksi gejala homoskedastisitas digunakan uji Glejser. Hasil probabilitas dikatakan signifikan jika nilai signifikansinya diatas tingkat kepercayaan 5\% (0,05). Berikut ini adalah tabel hasil uji Glejser:

Tabel 5.

Hasil Uji Glejser

\begin{tabular}{cccccc}
\hline \multicolumn{1}{c}{ Unstandardized Coefficients } & \multicolumn{2}{c}{ Standardized } \\
Coefficients & & \\
Model & B & Std. Error & Beta & T & Sig. \\
\hline
\end{tabular}


ISSN: 2302-8556

E-Jurnal Akuntansi Universitas Udayana

Vol.26.2.Februari (2019): 1570-1600

\begin{tabular}{llrrrrr}
\hline 1 & $-2,889$ & 3,012 & &,- 959 &, 340 \\
&,- 281 &, 365 &,- 089 &,- 771 &, 443 \\
& X1 &, 062 &, 201 &, 034 &, 310 &, 758 \\
& X2 & 3,382 & 3,009 &, 115 & 1,124 &, 264 \\
X3 &, 005 &, 014 &, 038 &, 359 &, 721 \\
X4 &, 601 &, 879 &, 076 &, 683 &, 496 \\
\hline X5 & & & & &
\end{tabular}

Hasil pengujian dalam tabel 5 menunjukkan bahwa seluruh variabel independen tidak berpengaruh terhadap nilai absolute residual. Nilai signifikansi masing-masing variabel diatas 0,05 sehingga bebas dari heteroskedastisitas.

Uji autokorelasi bertujuan untuk menguji apakah dalam model regresi linier ada korelasi antara kesalahan pengganggu pada periode $\mathrm{t}$ dengan kesalahan pengganggu pada periode t-1 (sebelumnya). Jika terjadi korelasi maka dinamakan ada problem autokorelasi. Untuk mendeteksi adanya autokorelasi digunakan Runs Test. Apabila nilai Asymp. Sig ( 2-tiled) diatas 0,05 maka diasumsikan resedual tidak terjadi autokorelasi antar nilai resedual. Hasil runs test dapat ditunjukkan dalam tabel 6.

Tabel 6.

Uji Autokorelasi

\begin{tabular}{ll}
\hline & Unstandardized Residual \\
\hline Test Value &, 09014 \\
Cases $<$ Test Value & 51 \\
Cases >= Test Value & 51 \\
Total Cases & 102 \\
Number of Runs & 57 \\
$Z$ &, 995 \\
Asymp.sig.(2-tailed) &, 320 \\
\hline
\end{tabular}

Sumber : Data diolah, 2019

Hasil uji runs test menunjukkan bahwa nilai Asymp. Sig ( 2-tiled) yang diperoleh sebesar 0,320 lebih besar dari 0,05 maka dapat disimpulkan tidak terdapat gejala autokorelasi.

Hasil uji analisis regresi linier berganda dalam penelitian ini dapat dilihat pada tabel berikut: 
Tabel 8.

Uji Statistik $\mathbf{t}$

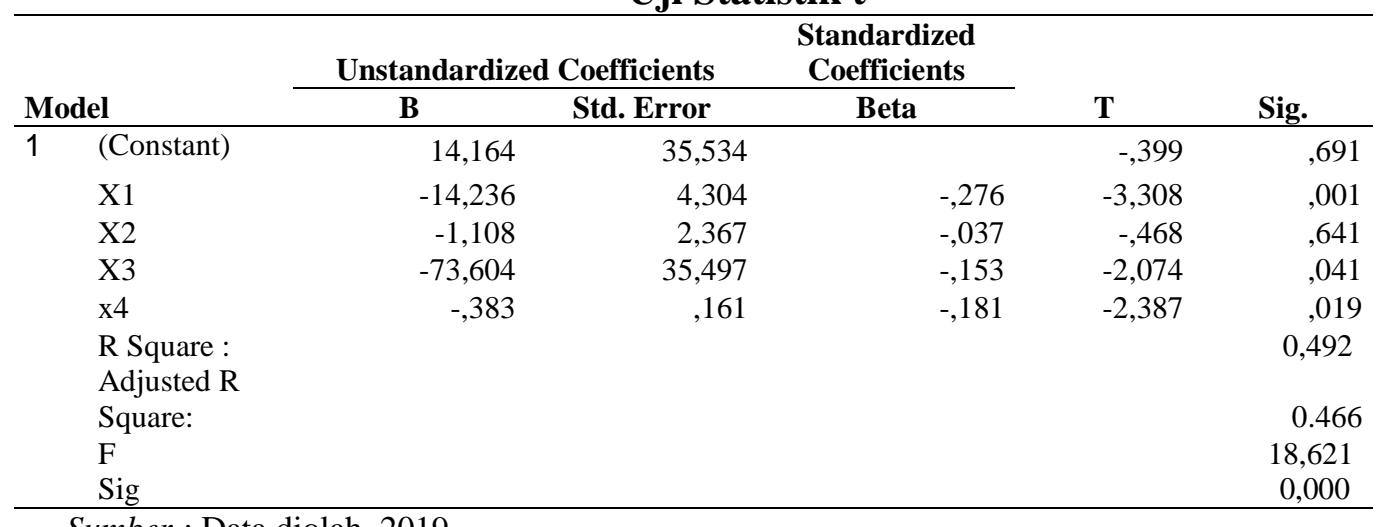

Sumber: Data diolah, 2019

Berdasarkan tabel diatas maka dapat disusun persamaan regresi sebagai

berikut:

$$
Y=14.164-14.236 X_{1}-1.108 X_{2}-73.604 X_{3}-383 X_{4}+e
$$

Hasil analisi kelayakan model $\mathrm{F}$ dapat dilihat menunjukkan bahwa nilai $\mathrm{F}$ hitung sebesar 18.621 dengan probabilitas 0,000 . Karena probabilitas jauh lebih kecil dari 0,05 maka model regresi dapat digunakan untuk memprediksi independensi komite audit (X1), keahlian komite audit (X2), keahlian audit internal (X3), jumlah audit internal dalam setahun ( X4) dan WBS (X5) secara bersama - sama berpengaruh terhadap pengungkapan kasus kecurangan.

Nilai adjusted $\mathrm{R}^{2}$ sebesar 0,466 menunjukkan bahwa sebesar $46,6 \%$ pengungkapan kasus kecurangan dipengaruhi oleh independensi komite audit $\left(\mathrm{X}_{1}\right)$, keahlian keuangan dan akuntansi yang dimiliki oleh anggota komite audit $\left(\mathrm{X}_{2}\right)$, keahlian keuangan dan akuntansi dari kepala unit audit internal $\left(\mathrm{X}_{3}\right)$, jumlah audit yang dilakukan oleh audit internal $\left(\mathrm{X}_{4}\right)$ serta whistleblowing system $\left(\mathrm{X}_{5}\right)$ sedangkan sisanya dipengaruhi oleh variabel - variabel lain diluar model. 
Dalam penelitian ini menggunakan hipotesis berarah (two-tile) sedangkan uji statistik dilakukan dengan uji satu arah (one-tile) sehingga untuk menerima atau menolak hipotesis yang diajukan harus melakukan uji parsial dengan membandingkan nilai $\mathrm{t}$ statistik atau $\mathrm{t}_{\text {hitung }}$ dengan $\mathrm{t}_{\text {tabel }}$. $\mathrm{H} 0$ diterima apabila nilai $\mathrm{t}_{\text {hitung }}<$ dari $\mathrm{t}_{\text {tabel }}$ dan $\mathrm{h} 1$ diterima apabila nilai $\mathrm{t}_{\text {hitung }}>$ nilai $\mathrm{t}_{\text {tabel }}$.

Berdasarkan hasil uji t pada tabel 8 menunjukkan bahwa variabel independensi komite audit (X1) memiliki nilai t hitung sebesar 3,308 lebih besar dari t tabel $(2,000)$ dengan tanda negatif dengan signifikansi uji t lebih kecil dari 0,05 yaitu sebesar 0,01. Hasil ini menunjukkan bahwa independensi komite audit (X1) berpengaruh negatif signifikan terhadap pengungkapan kasus kecurangan (Y) dengan kata lain hipotesis diterima. Koefisien regresi variabel X1 sebesar 14,236 hal ini berarti bahwa apabila variabel X1 meningkat satu satuan maka akan menurunkan kasus kecurangan sebesar 14,236 dengan asumsi bahwa variabel lain dianggap konstan. Variabel keahlian keuangan komite audit (X2) memiliki nilai t hitung $(-0,468)$ lebih kecil dari t tabel $(2,000)$ hal ini mengindikasikan bahwa keahlian keuangan komite audit tidak berpengaruh terhadap pengungkapan kasus kecurangan atau dengan kata lain hipotesis ditolak.

Hasil pengujian menunjukkan bahwa variabel audit internal yang diukur dengan keahlian keuangan yang dimiliki kepala satuan audit internal (X3) memiliki koefisien negatif sebesar 73,604 dengan tingkat signifikansi 0,41 lebih besar dari 0,05(tidak signifikan). Sedangkan nilai T hitung $(2,074)$ lebih besar dari t tabel (2,000). Hasil pengujian untuk variabel $\left(\mathrm{X}_{4}\right)$ menunjukkan bahwa semakin banyak kepala devisi audit internal memiliki keahlian keuangan $\left(\mathrm{X}_{4}\right)$ akan dapat 
Luh Utami, Lilik Handajani dan Hermanto. Evektifitas ...

menurunkan kasus kecurangan yang terjadi pada perusahaan meskipun tidak secara signifikan atau dengan kata lain hipotesis diterima. Hasil pengujian menunjukkan bahwa audit internal yang diukur dengan jumlah audit yang dilakukan oleh audit internal dalam setahun memiliki koefisien negatif sebesar 0,383 dengan signifikansi 0,19 lebih besar dari 0,05.(tidak signifikan). Sedangkan hasil uji parsial t hitung $(2,387)$ lebih besar daripada nilai t tabel $(2,000)$. Hasil tersebut menunjukkan bahwa jumlah audit yang dilakukan oleh audit internal $\left(\mathrm{X}_{4}\right)$ berpengaruh negatif terhadap pengungkapan kasus kecurangan atau dengan kata lain hipotesis diterima. Semakin banyak kegiatan audit yang dilakukan oleh audit internal dalam setahun akan dapat menurunkan kasus kecurangan di perusahaan meskipun tidak secara signifikan.

Analisis Moderated Regression Analysis (MRA) dalam penelitian ini digunakan untuk melihat efek interaksi antara variabel $\mathrm{X}_{1}, \mathrm{X}_{2}, \mathrm{X}_{3}, \mathrm{X}_{4}$ dan $\mathrm{X}_{5}$ sebagai variabel moderasi. Berikut adalah hasil uji Moderated Regression Analysis (MRA) :

Tabel 9.

Hasil MRA

\begin{tabular}{lrrrrr}
\hline \multirow{2}{*}{ Model } & \multicolumn{2}{c}{ Unstandarized Coeficcients } & \multicolumn{3}{c}{ Standarized Coeficcients } \\
\cline { 2 - 6 } & \multicolumn{1}{c}{ B } & Std. Error & Beta & t & Sig. \\
\hline 1 Constan & 55,645 & 5,362 & & 10,378 &, 000 \\
X1 & $-6,942$ & 3,831 &,- 134 & $-1,812$ &, 073 \\
X5 & $-74,513$ & 9,798 &,- 576 & $-7,605$ &, 000 \\
MODERATE_1 & $-22,623$ & 4,651 &,- 354 & $-4,864$ &, 000 \\
2 Constan & 58,275 & 5,366 & & &, 000 \\
X2 & $-1,216$ & 2,059 &,- 041 & 10,859 &, 556 \\
X5 & $-73,283$ & 9,081 &,- 567 & $-8,070$ &, 000 \\
MODERATE_2 & $-22,349$ & 3,967 &,- 391 & $-5,634$ &, 000 \\
& & & & &, 935 \\
3 Constan & $-2,504$ & 30,678 & &,- 082 &, 017 \\
X3 & $-74,881$ & 30,940 &, 156 & $-2,420$ &, 000 \\
X5 & $-57,789$ & 9,066 &,- 447 & $-6,374$ &, 000 \\
MODERATE_3 & $-42,448$ & 6,158 &,- 482 & $-6,893$ &, 000
\end{tabular}


ISSN: 2302-8556

E-Jurnal Akuntansi Universitas Udayana

Vol.26.2.Februari (2019): 1570-1600

\begin{tabular}{lccccc} 
X4 & $-2,533$ &, 567 & $-1,197$ & $-4,465$ &, 000 \\
X5 & $-75,416$ & 9,315 &,- 583 & $-8,096$ &, 000 \\
MODERATE_4 & $-3,563$ &, 675 & $-1,394$ & $-5,277$ &, 000 \\
\hline Sumber :Data diolah & 2019 &
\end{tabular}

Berdasarkan tabel 9 persamaan regresi dari hasil uji Moderate Regression Analysis adalah:

$$
Y=55,645-6,942 X_{1}-74,513 X_{5}-22,623 X_{1} X_{5}+e
$$

Nilai signifikansi untuk menguji interaksi $\mathrm{X}_{5}$ terhadap pengaruh $\mathrm{X}_{1}$ ke $\mathrm{Y}$ (moderate-1) adalah sebesar 0,000 lebih kecil dari 0,05 ( signifikan). Sedangkan uji parsial menunjukkan bahwa t hitung $(4,864)$ dibandingkan $t$ tabel $(2,000)$ atau dengan kata lain $\mathrm{t}$ hitung lebih besar dari t tabel sehingga hipotesis kelima diterima. Variabel moderasi (moderate_ 1) merupakan variabel moderasi semu (quasi moderator) karena $\mathrm{b}_{2}$ dan $\mathrm{b}_{3}$ signifikan. Hasil penelitian ini mendukung fraud triangle theory ada tiga unsur alasan seseorang melakukan kecurangan diantaranya adalah tekanan, kesempatan dan rasionalisasi. Dengan independensi yang dimiliki anggota komite audit akan membantu meningkatkan obyektivitas pengawasan yang dilakukan oleh komite audit sehingga kesempatan untuk melakukan tindakan kecurangan.

Penelitian ini sejalan dengan penelitian terdahulu yang dilakukan oleh Gusnardi (2017). Dimana komite audit berpengaruh terhadap kecurangan. Penelitian yang dilakukan oleh cahyo \& sulhani (2017) yang menguji pengaruh langsung antara komite audit independen dengan pengungkapan kecurangan menyebutkan bahwa komite audit independen tdak berpengaruh secara langsung terhadap kecurangan.

$$
\mathrm{Y}=58,275-1,216 \mathrm{X}_{2}-73,283 \mathrm{X}_{5}-22,349 \mathrm{X}_{2} \mathrm{X}_{5}+\mathrm{e}
$$


Nilai signifikansi untuk menguji interaksi $\mathrm{X}_{5}$ terhadap pengaruh $\mathrm{X}_{2}$ ke $\mathrm{Y}$ (moderate-2) adalah sebesar 0,000 lebih kecil dari 0,05 ( signifikan). Nilai t hitung $(5,864)$ lebih besar dari nilai $t$ tabel $(2,000)$ sehingga hipotesis keenam diterima. variabel moderasi (moderate_2) merupakan variabel moderasi semu (quasi moderator) karena $\mathrm{b}_{2}$ dan $\mathrm{b}_{3}$ signifikan.

Penelitian ini sejalan dengan penelitian terdahulu yang yang dilakukan oleh Gusnardi (2017), Prasetyo ( 2014) dimana komite audit berpengaruh langsung terhadap kecurangan. Penelitian ini juga mendukung hasil penelitian yang dilakukan oleh cahyo \& sulhani (2017) yang menguji pengaruh langsung antara komite audit dengan pengungkapan kecurangan menyebutkan bahwa keahlian keuangan komite audit tdak berpengaruh secara langsung terhadap kecurangan.

Hubungan antara komite audit, whistleblowing system terhadap pengungkapan kasus kecurangan memiliki pengaruh yang negatif dan signifikan . Dengan demikian, dapat diketahui bahwa whistleblowing system membantu pengawasan yang dilakukan oleh komite audit dalam rangka menurunkan tindak kecurangan yang terjadi.

$$
\mathrm{Y}=-2,504-74,881 \mathrm{X}_{3}-57,789 \mathrm{X}_{5}-42448 \mathrm{X}_{3} \mathrm{X}_{5}+\mathrm{e}
$$

Nilai signifikansi untuk menguji interaksi $\mathrm{X}_{5}$ terhadap pengaruh $\mathrm{X}_{3}$ ke $\mathrm{Y}$ (moderate_3) adalah sebesar 0,000 lebih kecil dari 0,05 ( signifikan). Hasil uji parsial menunjukkan bahwa t hitung $(6,893)$ lebih besar dari t tabel $(2,000)$ sehingga hipotesis ketujuh diterima. Variabel moderasi (moderate 3) merupakan variabel moderasi semu (quasi moderator) karena $\mathrm{b}_{2}$ dan $\mathrm{b}_{3}$ signifikan 
Hasil penelitian ini sejalan dengan penelitian yang dilakukan oleh Meikhati dan Rahayu ( 2015), Festi, Andreas \& Natariasari (2014) dimana komite audit berpengaruh terhadap fraud. Penelitian ini juga mendukung hasil penelitian yang dilakukan oleh nurcahyo \&sulhani (2017) dimana whistleblowing system tidak berpengaruh secara langsung terhadap kecurangan. Whistleblowing system akan menjadi alat bagi audit internal dalam mengungkap kasus kecurangan yang terjadi pada perusahaan.

$$
\mathrm{Y}=52,523-2,533 \mathrm{X}_{4}-75,416 \mathrm{X}_{5}-3,563 \mathrm{X}_{4} \mathrm{X}_{5}+\mathrm{e}
$$

Nilai signifikansi untuk menguji interaksi $\mathrm{X}_{5}$ terhadap pengaruh $\mathrm{X}_{4}$ ke $\mathrm{Y}$ (moderate-4) adalah sebesar 0,000 lebih kecil dari 0,05 (signifikan). Hasil uji parsial menunjukkan nilai t hitung $(5,277)$ lebih besar dari nilai t tabel 2,000 sehingga hipotesis kedelapan diterima. Variabel moderasi (moderate 4) merupakan variabel moderasi semu (quasi moderator) karena $\mathrm{b}_{2}$ dan $\mathrm{b}_{3}$ signifikan. Variabel whistleblowing system memoderasi hubungan antara jumlah audit yang dilakukan oleh audit internal dengan pengungkapan kasus kecurangan sekaligus merupakan variabel independen.

\section{SIMPULAN}

Hasil penelitian ini mendukung penelitian yang dilakukan oleh Festi \& Andreas (2017) serta Gusnardi (2011) yang menguji pengaruh langsung antara audit internal dan fraud dimana hasil penelitiannya menyatakan komite audit berpengaruh terhadap pencegahan kecurangan. Hasil penelitian ini juga sejalan dengan hasil penelitian yang dilakukan oleh Nurcahyo\& Sulhani (2017) dimana 
audit internal tidak berpengaruh secara langsung terhadap pengungkapan kasus kecurangan. Hal tersebut menunjukkan bahwa laporan - laporan yang masuk melalui whistleblowing system memerlukan tindak lanjut dari audit internal sebelum ditetapkan apakah laporan - laporan tersebut termasuk kedalam kasus kecurangan atau kasus kasus pelanggaran lain.

Hubungan antara audit internal, whistleblowing system, dan pengungkapan kasus kecurangan memiliki pengaruh yang negatif dan signifikan. Artinya, bahwa dengan adanya whistleblowing system dapat meningkatkan efektivitas audit internal dalam mengungkap kasus kecurangan yang terjadi. Audit internal harus menerima, menelaah dan menindaklanjuti pengaduan yang masuk melalui whistleblowing system sehingga dapat mengurangi kemungkinan kasus akan meluas dan melibatkan lebih banyak orang akan semakin kecil.

Beberapa keterbatasan dan saran dalam peneliian ini, yang dapat memberikan arah pada peneliti selanjutnya sebagai berikut:

Hasil penelitian menunjukkan bahwa variabel komite audit dan audit internal hanya mampu menjelaskan variabel pengungkapan kasus kecurangan sebesar $46.6 \%$ dan sisanya dipengaruhi variabel lainnya (lemah). Saran bagi peneliti selanjutnya adalah untuk menguji kembali dan menambahkan variabel independen lainnya yang mungkin berpengaruh terhadap pengungkapan kasus kecurangan seperti efektivitas auditor ekternal, kepemilikan manajerian dan ukuran perusahaan. 
Dalam penelitian ini whistleblowing system merupakan quasi moderator, sehingga dalam penelitian selanjutnya dapat menguji pengaruh langsung dari whistleblowing system terhadap pengungkapan kasus kecurangan.

Pada penelitian ini hanya mengukur whistleblowing system dari independensi dan keahlian keuangan yang dimiliki. Saran untuk peneliti selanjutnya adalah dengan memperluas indikator komite audit dan audit internal berdasarkan jumlah rapat yang dilakukan oleh komite audit. Karena dengan lebih banyak pertemuan yang maka evaluasi terhadap masalah - masalah yang dihadapi.

Berdasarkan kesimpulan yang telah disampaikan diatas, untuk itu perusahaan perlu melakukan peningkatan efektivitas komite audit dan audit internal serta whistleblowing system, antara lain sebagai berikut: Komite audit terbukti berpengaruh terhadap pengungkapan kasus kecurangan oleh karena itu diharapkan kepada perusahaan untuk tetap menjaga komitmennya dalam rangka pembentukan komite audit yang efektif secara independen dan jauh dari kepentingan pribadi, serta memiliki latar belakang pendidikan yang sesuai. Audit internal terbukti berpengaruh terhadap pengungkapan kasus kecurangan. Sehingga perlu bagi perusahaan untuk mengadakan pelatihan - pelatihan yang lebih intensif untuk anggota audit internal dalam rangka peningkatan efektivitas dan kompetensinya. Whistleblowing System terbukti memiliki efek quasi moderator terhadap pengugkapan kasus kecurangan. Dari hasil penelitian ini penting bagi perusahaan untuk meningkatkan pelaksanaan whistleblowing system karena selain mampu menurunkan kasus kecurangan secara langsung juga dapat membantu 
komite audit dan audit internal dalam mendeteksi kasus kecurangan sehingga jumlah kasus kecurangan yang terjadi pada perusahaan dapat diminimalisir.

\section{REFRENSI}

Abbott, L., Y. Park, and S. Parker. 2000. The effects of audit committee activity and independence on corporate fraud. Managerial Finance 26 (11): 55-67.

ACFE. 2016. Association of Certified Fraud Examiners'. http://www.aaajournals.org/doi/abs/10.2308/ajpt-51663? code=aaan-site.

Ajzen, Icek. 1991. The Theory of Planned Behavior‘. Orgnizational Behavior and Human Decision Processes 50: 179-211. http://www.sciencedirect.com/science/article/pii/074959789190020T.

Albrecht, W. S., C. O. Albrecht and C. C. Zimbelman.2011. Fraud Examination, 4th Edition (Cengage Learning: Mason, Ohio).

Amrizal. 2004. Pencegahan dan Pendeteksian Kecurangan oleh Auditor Internal. www.bpk.go.id

Arikunto, Suharsimi.2002. Metodologi Penelitian. Jakarta: Penerbit PT. Rineka Cipta.

Association of Certified Fraud Examiners (ACFE).2000. "Report to Nation". http:// marketplace.cfenet.com/Download.asp

Beasly, M. S. (1996). An Empirical Analysis of the Relation Between the Board of Director Composition and Financial Statement Fraud. The Accounting Review, 71(4), 443-465

Agusyani, K.S., Sujana, E \& Wahyuni, M.A. 2016. Pengaruh Whistleblowing System dan Kompetensi Terhadap Fraud Pada Pengelolaan Keuangan Penerimaan Pendapatan Asli Daerah ( Studi Pada Dinas Pendapatan Daerah Kabupaten Buleleng). E- Journal S1 ak Universitas Pendidikan Ganesha Jurusan Akuntansi Program S1, Volume 6 (3.

Anggriawan, Eko Ferry (2014). Pengaruh Pengalaman Kerja Skeptisme Profesional, dan Tekanan Waktu Terhadap Kemampuan Auditor Dalam Mendeteksi Fraud ( Studi Empiris Pada Kantor Akuntan Publik di DIY). JURNAL NOMINAL. 3 (2):101-116. 
Cahyo dan Sulhani.2017. Analisis Empiris Pengaruh Karakteristik Komite Audit, Karakteristik Internal Audit, Whistleblowing system, Pengungkapan Kecurangan Terhadap Reaksi Pasar. Jurnal Dinamika Akuntansi dan Bisnis. 4(2):249-270.

Cressy, Donad R 1953. Other People Money, Study in The Social Psichology of Embezzlement. Monclain,JN: Patterson Smith

Dorminey, Jack, A. Scott Fleming, Mary-Jo Kranacher, and Richard A. Riley Jr.. (2012). The Evolution of Fraud Theory. Issues in Accounting Education American Accounting Association, Vol. 27, No. 2 (2012).

Davis, F.D.,1986. Tecnology Acceptance Model for Empirically Testing New End User Information System Theory and Result. Unpublished Doctoral Dissertation MIT.

Dwiharyadi.2014. Pengaruh Keahlian Akuntansi dan Keuangan Komite Audit dan Dewan Komisaris Terhadap Manajemen Laba. Jurnal Akuntansi dan Keuangan Indonesia. 14 (1):75-93.

Dwiputri, Intan Izzati. (2013). Analisis pengaruh pengungkapan etika dan unsur good corporate governance terhadap kemungkinan kecurangan laporan keuangan (Studi empiris pada perusahaan manufaktur yang terdaftar di Bursa Efek Indonesia). Journal of Accounting, 1(1):9-16.

Elias, Rafik, and Rafik Elias. 2008. =Auditing Students ' Professional Commitment and Anticipatory Socialization and Their Relationship to Whistleblowing'.http://www.emeraldinsight.com/doi/abs/10.1108/02686900 810857721 .

Fatmawati, S.2015. Pengaruh Whistleblowing System dan Efektivitas Audit Internal Terhadap Pendeteksian dan Pencegahan Kecurangan ( Fraud). ( Skripsi Tidak Dipublikasi Univ. Pasundan Bandung)

Festi Thresa, Dr. Andreas, Riaka Natariasari. 2014. Pengaruh Peran Audit Internal Terhadap Pencegahan Kecurangan. JOM FEKOM.1 (2).

Festinger, L. 1954. A Theory Of Cognitive Dissonance. Standford : Standford University Press.

Ghozali, Imam.2006. Aplikasi Analisis Multivariate dengan Program SPSS. Semarang: Penerbit Universitas Diponegoro.

2016. Aplikasi Analisis Multivariate dengan Program IBM SPSS 23. Semarang: Penerbit Universitas Diponegoro. 
Guna \& Herawaty. 2010. Pengaruh Mekanisme Good Coorporate Governance, Independensi Auditor, Kualitas audit Dan Faktor Lainnya Terhadap Manajemen Laba .Jurnal Bisnis dan Akuntansi.12 (1), 53-56.

Gusnardi.2011. Pengaruh Peran Komite Audit, Pengendalian Internal, Audit Internal dan Pelaksanaan Tata Kelola Perusahaan Terhadap Pencegahan Kecurangan. Ekuitas. 15 (1):130-146.

Handoko, Bambang Leo dan Ramadhani, Kinanti Ashari.2017. Pengaruh Karakteristik Komite Audit, Keahlian Keuangan Dan Ukuran Perusahaan Terhadap Kemungkinan Kecurangan Laporan Keuangan. DeReMa Jurnal Manajemen.12(1):86-112.

Kalbers, Lawrence P,. Dan Fogarty, Timoty J. 1995. Profesionalism Its Consequences: A Study of Internal Auditors. Auditing: A Journal of Practice. Vol 14. No.1:64-86.

Kamarudin, Khairul Anwar.,\& Ismail, Wan Adibah Wan. 2014. The Effects of Audit Commitee Attributes on fraudelent financial Reporting. Journal of Modern Accounting and Auditing. 10 (5).508-514

Kartika, Sekar Niken., \& Sudarno. 2014. Analisis Pengalaman Pra Komite Audit Terhadap Pendeteksian Kecurangan Pelaporan Keuangan. Diponegoro Journal of Accounting. 3 (3).1-10.

Karyono, 2013. Forensic Fraud. Yogyakarta: Pnenerbit Andi.

Kassem, Rasha and Higson, Andrew. (2012). The New Fraud Triangle Model. Journal of Emerging Trends in Economics and Management Sciences (JETEMS) 3(3), 2012.

Komite Nasional Kebijakan Governance. (2008). Sistem Pelaporan PelanggaranSPP (Whistleblowing System-WBS). Jakarta.

Kusumaningrum.w.a \& Murtanto (2016). Analisis Pengaruh Fraud Diamond Dalam Mendeteksi Kecurangan Laporan Keuangan. Seminar Nasional dan Call Paper Fakultas Ekonomi UNIBA Surakarta. Invesment Challenges and Opportunities in Indonesian Capital Market in The Era of Asean Economic Community. ISBN : 978-979-1230-36-0

Kusumawardhani, Prisca. 2014. Deteksi Financial Statement Fraud Dengan Analisis Fraud Triangle Pada Perusahaan Perbankan Yang Terdaftar Di BEI. Jurnal Akuntansi Unesa. 1 (3). 
Koroy, Tri Ramaraya. 2008. Pendeteksian Kecurangan (Fraud) Laporan Keuangan oleh Auditor Eksternal. Jurnal Akuntansi dan Keuangan, Volume 10, No.1.

Lee, G., \& Fargher, N. (2012). Companies' use of whistle-blowing to detect journal anagerial finance fraud: an examination of corporate whistleblowing policies. Journal of Business Ethics, 114, 283-295.

Lestari, I.T., Gunawan, H \& Purnamasari, P. 2016. Pengaruh Peran Audit Internal dan Efektivitas Whistleblowing System Terhadap Pencegahan Fraud ( Survei pada Bank Umum Syariah di kota Bandung, Jawa Barat). Proceding Akuntansi Volume 2, No.1 Tahun 2016, 2205-212.

Martono, Nanang.2012. Metode Penelitian Kuantitatif: Analisis Isi dan Analisis Data Sekunder. Jakarta:Rajawali Press.

Maliawan, Sujana dan Diatmika. 2017. Pengaruh Audit Internal dan Efektivitas Pengendalian Intern Terhadap Pencegahan Kecurangan (Fraud). e-Journal S1 Ak Universitas Pendidikan Ganeca. 8(2).

Mustafa, Sameer., T \& Youssef Nouhene Ben. 2012. Audite Committee Financial Expertise And Missappropriation And Assets. Managerial Auditing Journal. 25 (3).208-228.

Mustika, D. 2016. Pengaruh Red Flags, Whistleblowing System, Profesionalisme Auditor Internal Terhadap Pendeteksian Kecurangan Laporan Keuangan. Tesis Tidak Dipublikasi, Universitas Islam Negeri Syarif Hidayatullah Jakarta.

Natalia, Devina, 2012. “ Peran Sikap Profesionalisme Auditor Internal Dalam Mengungkap Temuan Audit “ Jurnal Berkala Ilmiah Mahasiswa Akuntansi, Vol.1, No.2.

Noviani, D.P. \& Sambharakreshna, Y.2014. Pencegahan Kecurangan Dalam Organisasi Pemerintahan. JAFFA Oktober, Vol.2, No.2. Hal. 61 - 67

Otoritas Jasa Keuangan. 2015. Peraturan Otoritas Jasa Keuangan No. 55/PJOK.04/2015 tentang pembentukan dan pedoman pelaksanaan Kerja Komite Audit. Jakarta:OJK.

Otoritas Jasa Keuangan. 2015. Peraturan Otoritas Jasa Keuangan No. 56/PJOK.04/2015 tentang pembentukan dan penyusunan piagam unit audit internal. Jakarta:OJK. 
Pradita \& Ngumar.2017. Persepsi Auditor Internal Terhadap Persepsi Penanganan Fraud yang Terjadi di Perusahaan. Jurnal Ilmu dan Ridet Akuntansi. 6 (8):115 .

Prasetyo, Adrian Budi.2014. Pengaruh Karakteristik Komite Audit Dan Perusahaan Terhadap Kecurangan Pelaporan Keuangan. Jurnal Akuntansi Dan Auditing. 11 (1):1-24.

Ragunandan, et al. 2001. “ Audit Committee Composition Gray Directors, And Interaction With Internal Auditing”. Accounting Horizon. Vol.15,No.2, Hal.105.

Rustendi, Tedi. 2009. Analisis Terhadap Faktor-Faktor yang Memicu Terjadinya Fraud. Jurnal Akuntansi Vol 4. Nomor 2, Juli-Desember 2009.

Sagara, Y. 2013. Profesionalisme Internal Auditor dan Intensi Melakukan Whistleblowing System. Jurnal Liquidity, Vol.2, No.1:34-44.

Skousen, Christopher J., and Brady James Twedt. 2009. Fraud Score analysis in emerging markets. Cross Cultural Management Vol 16: $301-316$.

Skousen, Christopher J., Kevin R. Smith, Charlotte J. Wright. 2009. Detecting and Predicting Financial Statement Fraud: The Effectiveness of The Fraud Traingle and SAS No. 99. http://ssrn.com/abstract=129549 $\underline{4}$

Srimulyani dan Ismatullah. 2017. Pengaruh Audit Internal Dalam Pencegahan Kecurangan Kas Pada PDAM Tirta Bumi Wibawa Kota Sukabumi. Jurnal Ilmiah Ilmu Ekonomi Vol.5:109-116.

Suginam. 2017. Pengaruh Peran Audit Internal dan Pengendalian Intern Terhadap Pencegahan Fraud. Riset dan Jurnal Akuntansi. 1(1):22-28.

Sugiyono.2008. Statistika untuk Penelitian. Bandung. Alfabeta 2009. Metode Penelitian Kualitatif dan Kuantitatif. Bandung. Alfabeta. 2014. Metode Penelitian Bisnis. Bandung. Alfabeta.

Sukirman dan Sari, Maylia Pramono.2013. Model Deteksi Kecurangan Berbasis Fraud Triangle. Jurnal Akuntansi \& Auditing.9(2):199-225.

Surat Edaran Mahkamah Agung No. 4 Tahun 2011 Tentang Perlakuan Bagi Pelapor Tindak Pidana ( Whistleblower) Dan Saksi Pelaku Yang Bekerjasama ( Justice Collaborators) Didalam Perkara Tindak Pidana Tertentu. 
Surat Edaran Otoritas Jasa Keuangan Nomor.32/SEOJK.04/2015 Tentang Pedoman Tata Kelola Perusahaan Terbuka.

Siregar, S. V., and Tenoyo.B. 2015. Fraud awareness survey of private sector in Indonesia. Journal of Financial Crime. 22 (3): 329 - 346.

Terry, D. J., O'Leary, J. E., 1995, “The Theory of Planned Behaviour: The Effects of Perceived Behavioural Control and Perceived Self - Efficacy", British Journal of Social Psycho-logy, 34,199- 220.

Tiffani , Laila.2015. Deteksi Financial Statement Fraud Dengan Analisis Fraud Triangle Pada Perusahaan Manufaktur Yang Terdaftar Di Bursa Efek Indonesia. JAAI.19(2):112-125.

Tuanakotta, Theodorus M. 2010. Akuntansi Forensik dan Audit Investigatif. Salemba Empat. Jakarta.

Widaningsih, Mimin dan Hakim, Desy Nur.2015. Pengarug Profesionalisme Auditor Internal Terhadap Pencegahan dan Pendeteksian Kecurangan. Jurnal Riset akuntansi dan Keuangan.3(1).586-602.

Widhilestariningtyas \& Rahman. 2014. Pengaruh Audit Internal Terhadap Resiko Fraud ( Survey Pada PT BRI Di Wilayah Bandung. Jurnal Riset Akuntansi.VI (1):19-37.

Widiyastuti, Marcelina \& Sugeng. 2009. Pengaruh Kompetensi, Independensi, Dan Profesionalisme Terhadap Kemampuan Auditor Dalam Mendeteksi Kecurangan. Value Added Majalah Ekonomi dan Bisnis, Vol.7, No.2 : 3153.

Wolfe, David T., and Dana R. Hermanson. 2004. The Fraud Diamond: Considering The Four Element of Fraud. CPA Journal. 74.12: 38-42.

Yusriwati.2017. Pengaruh Peran Audit Internal Terhadap Pencegahan Kecurangan Pada Perusahaan Perbankan di Pekanbaru. Jurnal Akuntansi dan Keuangan. 6(2):1-13.

Zulganef, 2008. Metode Penelitian Sosial dan Bisnis. Yogyakarta: Graha Ilmu. 